\title{
Failure case of a garage door opener
}

\author{
K. Habib* and A. Al-Hazzaa*
}

\begin{abstract}
A failure analysis of a garage door opener was conducted for determination of the cause of the failure. The analysis included visual inspections of broken parts as well as electron microscopy examinations of the fracture surface. The visual inspections showed that a bolt connected to the inner trolley of the garage opener assembly was initially fractured. Also, the results of electron microscopy examinations revealed that the broken bolt failed by fatigue damage phenomenon, due to alternating torsional stresses through out 25 years of an operational life of the garage opener. In addition, a mathematical model corresponding to the failure mechanism was derived along the failure analysis. The model comprises of both design philosophy and fracture mechanics approaches.
\end{abstract}

Keywords Failure analysis. Fatigue damage. Fracture mechanics. Scanning electron microscopy (SEM). Mathematical model. Modified Goodman diagram.

\section{Fallo del mecanismo de apertura de una puerta de garaje}

Resumen

\begin{abstract}
Se analizó el fallo del mecanismo de apertura de una puerta de garaje con el fin de determinar sus causas. El análisis incluyó una inspección visual de las piezas rotas así como un examen mediante microscopia de la superficie de fractura. La inspección visual reveló que primero se fracturó un perno conectado al carro interior del mecanismo de apertura. Los resultados del análisis por microscopía electrónica también mostraron que el perno roto falló debido a fenómenos de daño por fatiga, debido a los esfuerzos torsionales alternos a la largo de 25 años de vida en servicio del mecanismo de apertura. Por otra parte, se construyó un modelo matemático correspondiente al mecanismo de rotura durante el análisis del mismo. Este modelo comprende enfoques, tanto de la filosofía de diseño como de la mecánica de fractura.
\end{abstract}

Palabras clave Análisis de fallo. Daño por fatiga. Mecánica de fractura. Microscopía electrónica. Modelo matemático. Diagrama Goodman modificado.

\section{INTRODUCTION}

Broken parts of a garage door opener was submitted to the materials science laboratory, of KISR, for determination of the cause of the failure. The broken parts were a $0.625 \mathrm{~cm}$ UNC bolt $(0.25$ inch) connected through a cable to the inner trolley of the garage door-opener assembly. The bolt has a major diameter of $0.625 \mathrm{~cm}$, a minor diameter of $0.477 \mathrm{~cm}, 20$ threads per inch, and a pitch diameter of $0.545 \mathrm{~cm}$. The garage door size is for two car garage. The garage door opener has been used, on an average, from 2-4 times per day for 25 years in a residential dwelling, before the failure occurred. A schematic drawing of the garage door opener is shown in figure 1a, indicating the broken bolt location in the inner trolley of the garage door- opener assembly and the broken bolt as items 1 and 2 , respectively. Also, the schematic drawing shows, in figure $1 \mathrm{~b}$, the geometry of the connecting bolt. From figure $1 \mathrm{~b}$, it is most likely that the connecting bolt has gone through alternating tensional stresses first, because of the operational nature of the garage door-opener. Then, the connecting bolt has gone through torsional stresses due to a misalignment of the cable, between the connecting bolt and the trolley, later in time, before the failure occurred.

\section{EXPERIMENTAL WORKS}

\subsection{Visual inspection}

A visual inspection of the broken parts indicates that the broken bolt, see figure 1, has initially

(*) Materials Science Lab., Department of Advanced Systems, Chemical Analytical Lab., KISR, P.O. Box 24885, SAFAT, 13109 Kuwait. 


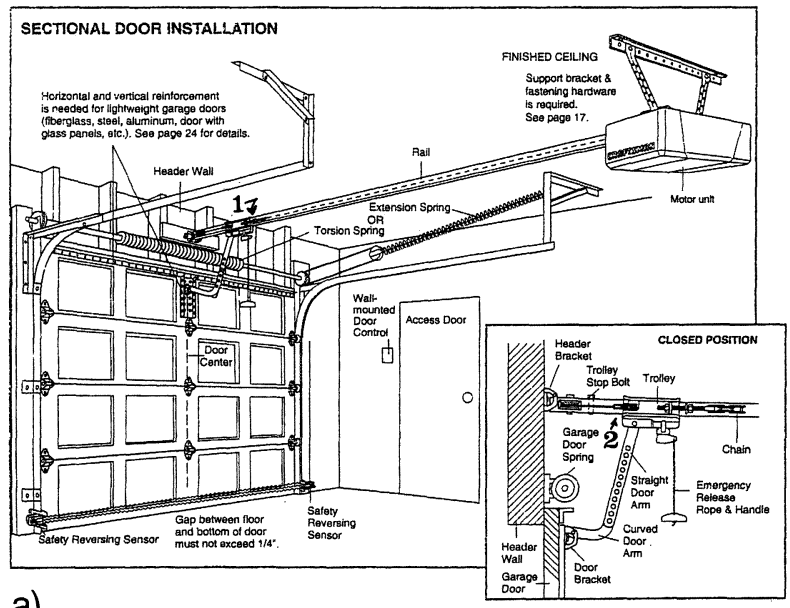

a)

b)
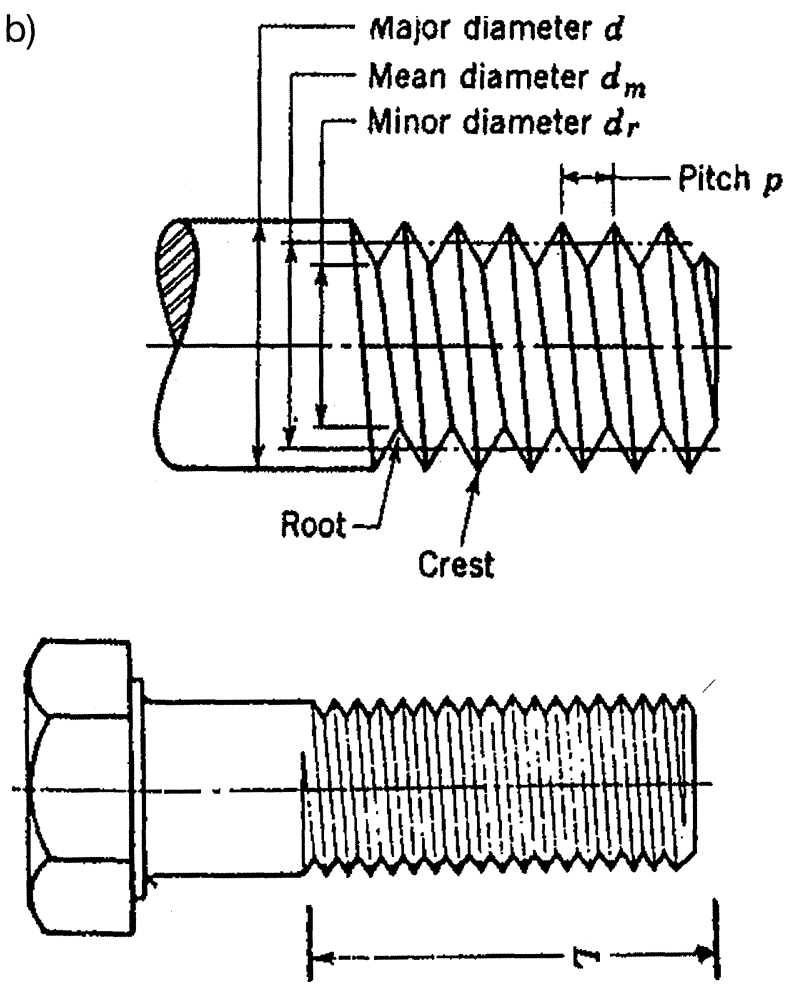

Figure 1. a) A schematic drawing of the garage door, indicating the broken bolt location in the inner trolley of the garage door-opener assembly and the broken bolt as items 1 and 2, respectively. Also, the schematic drawing shows, in Figure $1 b$, the geometry of the connecting bolt.

Figura 1. a) Esquema de la puerta del garaje indicando la localización del perno roto en la polea interna de la unión puerta-abridor y el perno roto señalados por 1 y 2 respectivamente, b) Esquema mostrando la geometría del perno de unión.

suffered from a brittle fracture at and near the outer surface of the bolt, followed by an overloading, plastic deformation at the middle of the fracture surface. These findings are based on distinguished features of the fracture surface of the bolts. The fracture surface was found to consist of two distinguished regions. One is a smooth and flat region, surrounding the outer surface of the bolt, in which multi-cracks had initiated and propagated in a brittle fashion. The other is a $45^{\circ}$ inclined region, in the middle of the fracture surface, indicating the final rupture was due to a plastic deformation. In other words, many cracks were initially triggered from the surface of the bolt and propagated along a direction of $90^{\circ}$ with respect to loading axis of the bolt, until the cross sectional area of the bolt was reduced to the point that the loading capability of the bolt was no longer able to handle the loading. As a result, rapid plastic deformation occurred along the plane of the maximum shear stress, in the middle of the fracture surface.

\subsection{Chemical composition analysis}

A quantitative WDS (wavelength dispersive spectroscopy), microanalysis revealed that the composition of the material of the connecting bolt is (weight \%) 0.173 C, $0.76 \mathrm{Mn}, 0.72 \mathrm{Cr}, 0.17$ Mo, $0.65 \mathrm{Ni}, 0.2 \mathrm{Si}, 0.09 \mathrm{P}, 0.025 \mathrm{~S}$ and balance Fe. Accordingly, the material of the bolt is determined to be of a low alloying steel classified as a nickel, chromium, molybdenum low alloy steel. Also, the materials was found to have a hardness value around RB 59 (Rockwell hardness B scale), with ferritic and pearletic microstructures, see figure 2 for the microstructures of the broken bolt. From the literature ${ }^{[1]}$ this sort of material is typically used for relatively light transmission components.

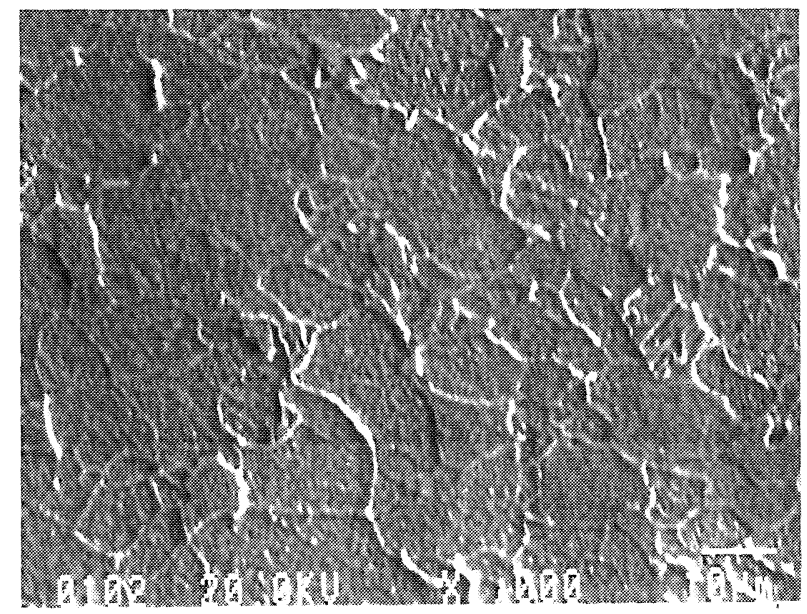

Figure 2. The microstructures of the broken bolt.

Figura 2. Microestructura del perno roto. 


\subsection{Electron microscopy examinations}

Examinations of the fracture surface of the bolt by a scanning electron microscope (SEM) lead to the following conclusions:

- Failure of the bolt initially occurred due to a consequence of multi-sites of crack nucleation from the bottom of the threads of the bolt along the circumference of the bolt, where the local stress concentration had exceeded the critical stress concentration. Figure 3 shows an example of multi-sites of the crack nucleation which emanated from the bottom of the threads along the circumference of the bolt. In addition, figure 3 shows a flat region next to the bottom of the threads a long the circumference of the bolt and a rough (inclined) region in the middle of the sample.

- SEM examinations revealed that the brittle failure of the bolt occurred due to fatigue damage phenomenon due to alternating torsional stresses. This finding is based on the documentation of fatigue striations along the direction of the crack propagation. Figure 4 is a fracture surface obtained from the flat and smooth area of the surface. It also exhibits fatigue striations along the crack propagation

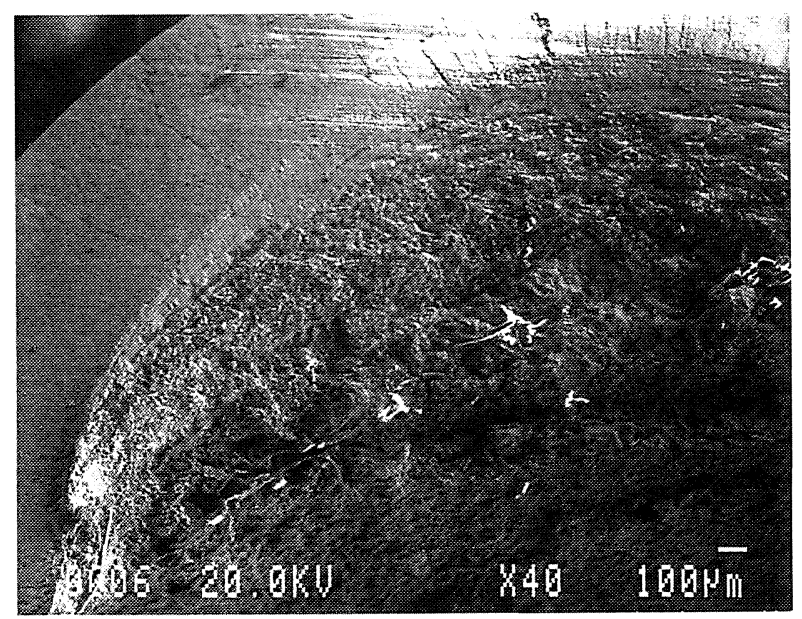

Figure 3. Multi-sites of the crack nucleation which emanated from the bottom of the threads along the circumference of the bolt. Also, Figure 3 shows a flat region next to the bottom of the threads a long the circumference of the bolts and a rough (inclined) region in the middle of the sample.

Figura 3. Múltiples lugares de nucleación de la grieta que se inician desde la base de la rosca a lo largo de la circunferencia del perno. También se muestra una superficie plana próxima a la base de la rosca a lo largo de la circunferencia del perno y una zona deformada en la mitad de la muestra.

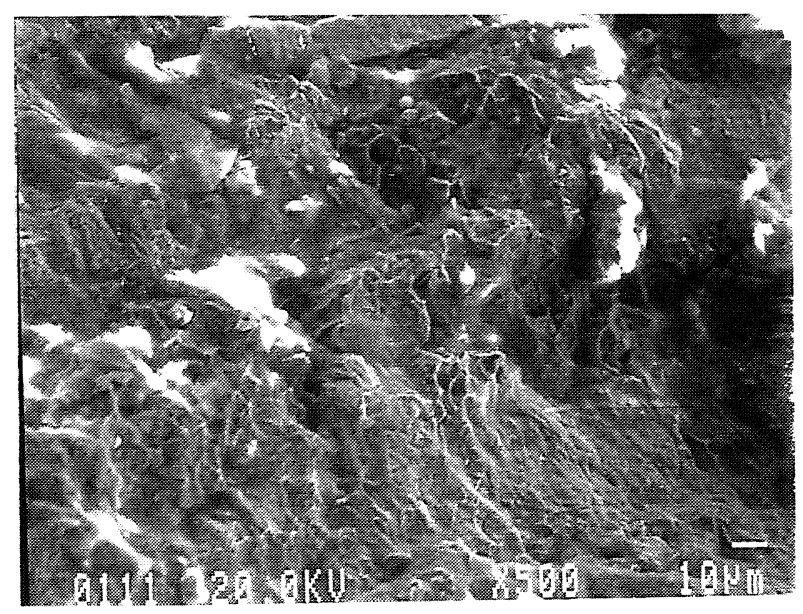

Figure 4. SEM image of smooth and flat area of the fractured surface showing striations along the crack propagation direction. The striation spacing is nearly $14 \mu \mathrm{m}$.

Figura 4. Imagen de MEB de una superficie pulida, correspondiente a la superficie de fractura, mostrando estrías a lo largo de la dirección de propagación. El espacio entre estrías es aproximadamente de $14 \mu \mathrm{m}$.

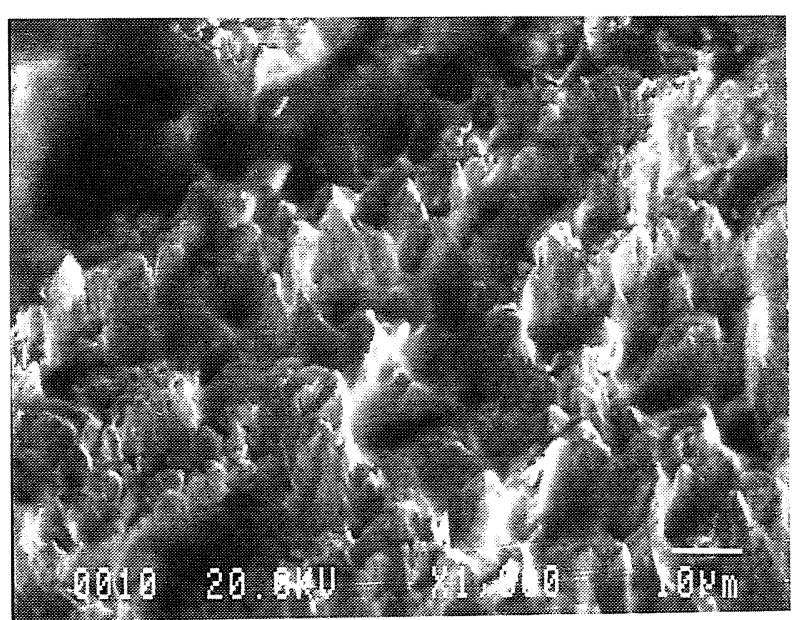

Figure 5. Represents a fracture surface obtained from the incline region in the middle of the surface. Figure 5 exhibits a typical cup and cone of a ductile fracture, due to the over loading of the final failure of the bolt.

Figura 5. Superficie de fractura obtenida sobre la región inclinada de la mita de la superficie. Se muestra una fractura típica con picos y hendiduras debido a la sobrecarga de la rotura final del perno.

path. The spacing between the striations is nearly $14 \mu \mathrm{m}$. This observation is in agreement with works published in literature elsewhere ${ }^{[2]}$. In addition, figure 5 represents a fracture surface obtained from the incline region area in the middle of the surface. It is obvious that figure 5 exhibits a typical cup and cone of a ductile fracture, due to the over loading of the final failure of the bolt.

Rev. Metal. Madrid Vol. Extr. (2005) 340-344 


\section{MATHEMATICAL MODEL}

In order to describe the way that the connecting bolt failed from a design philosophy and fracture mechanics point of views, the following analysis is considered. The connecting bolt has specifications defined as (see Fig. 1).

$\mathrm{d}=0.626 \mathrm{~cm}$ (major diameter),

$\mathrm{p}=0.545 \mathrm{~cm}$ (screw pitch),

$\mathrm{T}=105 \mathrm{Kg}-\mathrm{m}$ (tightening torque).

Hence, one can analyze the design of the bolt against fatigue failure from any standard design text to determine whether the bolt is subjected to fatigue damage or not under normal operational conditions. From a design philosophy reported by Shigley ${ }^{[3]}$ on bolts design against fatigue damage, the alternative tensional stress of the bolt is defined as:

$$
\sigma_{\mathrm{a}}=\frac{\mathrm{K}_{\mathrm{b}}}{\mathrm{K}_{\mathrm{b}}+\mathrm{K}_{\mathrm{m}}} \cdot \frac{\mathrm{F}}{2 \mathrm{~A}_{\mathrm{t}}}
$$

where,

$K_{m}=2 \pi d^{2} E / L$ (Stiffness constant),

$K_{b}=\pi d^{2} E / 4 L$ (Stiffness of the bolt),

$\mathrm{F}=\sigma_{\mathrm{p}} \mathrm{A}_{\mathrm{t}}$ (External load on the bolt),

$A_{t}=(\pi / 4) d_{m}^{2}$ (Tensile stress area of the bolt),

$\mathrm{E}=$ modulus of elasticity of the bolt material,

$\mathrm{L}=$ The total thickness of the parts which have been fastened together (see Fig. 1),

$\sigma_{\mathrm{p}}=$ Proof stress of the bolt (material property),

$\mathrm{d}_{\mathrm{m}}=(\mathrm{d}+\mathrm{dr}) / 2=\mathrm{cm}$ Mean diameter of the bolt,

$d_{r}=d-1,280655 p=$ Minor diameter of the bolt Also, the mean stress in the bolt is defined as:

$$
\sigma_{\mathrm{m}}=\sigma_{\mathrm{a}}+\mathrm{Fi} / \mathrm{A}_{\mathrm{t}}
$$

where,

$\mathrm{F}_{\mathrm{i}}=\mathrm{T} / \mathrm{r}=$ the preload (initial) load of the bolt, $\mathrm{r}=\mathrm{d} / 2=$ radius of the bolt.

Since $\sigma_{\mathrm{a}}$ and $\sigma_{\mathrm{m}}$ can be calculated from knowing the dimensions of the bolt and the material properties, thus a point of $\left(\sigma_{\mathrm{a}}, \sigma_{\mathrm{m}}\right)$ can be plotted in a modified Goodman diagram ${ }^{[3]}$ after calculating the endurance fatigue limit of the bolt. This allows to determine whether the design of the bolt against fatigue has a finite or infinite life. Since the endurance limit of the bolt is define as ${ }^{[3]}$

$$
\mathrm{S}_{\mathrm{e}}=\mathrm{K}_{\mathrm{a}} \mathrm{K}_{\mathrm{b}} \mathrm{K}_{\mathrm{e}} \mathrm{K}_{\mathrm{d}} \sigma_{\mathrm{ut}}
$$

where, $\mathrm{K}_{\mathrm{a}}, \mathrm{K}_{\mathrm{b}}, \mathrm{K}_{\mathrm{e}}, \mathrm{K}_{\mathrm{d}}$ are constants and can be determined based on the conditions of the material, and $\sigma_{\mathrm{ut}}=$ ultimate tensile stress of the bolt material.

Therefore, a modified Goodman diagram can be plotted in which if the point $\left(\sigma_{\mathrm{a}}, \sigma_{\mathrm{m}}\right)$ is found within the triangle 0 Se $\sigma_{\mathrm{u}}$, this leads to an infinite fatigue life (see Fig. 6). On the other hand, if the point is found outside the triangle, this leads to a finite fatigue life. As a result, the bolt is expected to fail within a certain number of cyclic loading.

It is worth noting that, in the case of designing against fatigue damage of the bolt due to the alternative torsional stress as in the present case, the above mathematical analysis is applicable ${ }^{[3]}$ with changing the tensile stress area $\left(A_{t}\right)$ of the bolt to the shear stress area of the bolt (As), alternating tensile stress $\left(\sigma_{\mathrm{a}}\right)$ to alternating torsional stress $(\tau \mathrm{a})$, and mean tensile stress $\left(\sigma_{\mathrm{m}}\right)$ to torsional mean stress $(\mathrm{tm})$. One must also use the shear modulus of elasticity $(\mathrm{G})$ rather than the modulus of the elasticity (E). The relationship between $G$ and $E$ is defined as the following:

$$
E=2 G(1+\mu)
$$

where $\mu$ is the Poisson ratio of the bolt material, a property constant of the material. Furthermore, one must use the torsional endurance limit (Sse) rather than the tensile endurance limit (Se), in

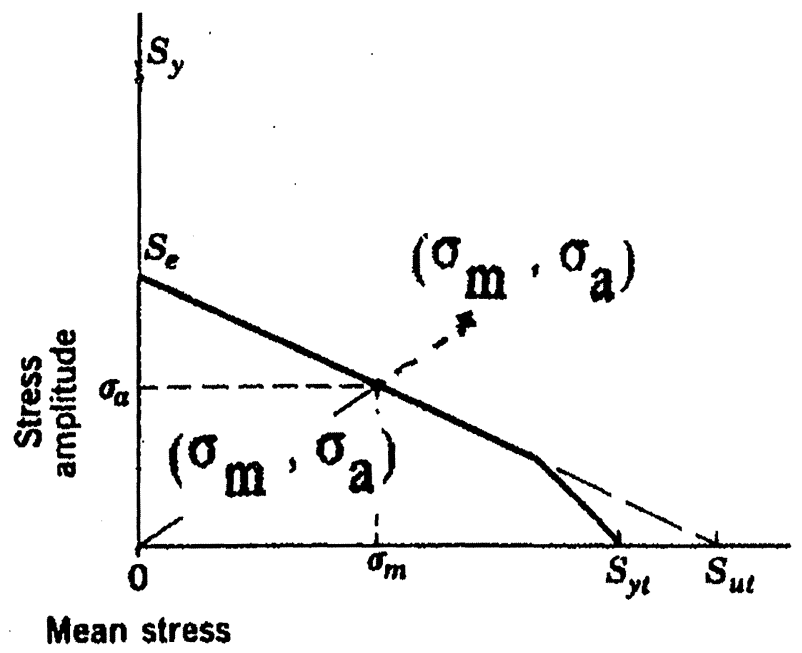

Figure 6. A modified Goodman diagram showing finite and infinite fatige life corresponding to the two positions of the point $\left(\sigma_{\mathrm{m}}, \sigma_{\mathrm{a}}\right)$.

Figura 6. Diagrama de Goodman modificado, mostrando límites de fatiga finito e infinito dados por las dos posiciones del punto $\left(\sigma_{m}, \sigma_{a}\right)$. 
which that the criterion of fatigue failure of the bolt is indicated if

$$
\tau \mathrm{a}=\text { Sse }
$$

In the present failure case, we assume that the design of the bolt was safe to sustain fatigue damage however for one reason or another the bolt failed for unaccountable factors such as sharp stress concentration at the bottom of the bolt thread (see Fig. 3). Also, from the striation spacing in figure 4 , one can determine the stress intensity factor range during the propagation region of the crack from a fracture mechanics approach. The striation spacing is defined as ${ }^{[4]}$

$$
S=6(\Delta \mathrm{K} / \mathrm{E})^{2}
$$

where $\Delta K=$ stress intensity factor range for the crack propagation. By knowing $\mathrm{S}, \Delta \mathrm{K}$ can be calculated. Since the criterion for safe design from fracture mechanics that $\Delta \mathrm{K}$ must be less than $\Delta \mathrm{K}_{\mathrm{th}}$, where $\Delta K_{\text {th }}$ is the stress intensity factor range for the threshold of crack propagation. Consequently, this leads to the fact that during the cyclic loading of the bolt $\Delta \mathrm{K}$ exceeded $\Delta \mathrm{K}_{\mathrm{th}}$ due to the presence of the stress concentration risers such as the one presented in figure 3, so eventually that led to the failure of the bolt.

\section{REFERENCES}

[1] W. SMITH, Principle of Materials Science and Engineering, McGraw-Hill, New York, 1986, p. 477.

[2] L. Engel And H. Klinge, Atlas of the Metal Damage, Printice Hall, New York, 1981, p. 80.

[3] J. Shigley, Mechanical Engineering Design, McGraw-Hill Book Co., 3rd Edition, New York, 1977, pp. 208-227.

[4] R. Hertzburg, Fracture Mechanics of Engineering Materials, John Wiley \& Son, 2nd Edition, New York, 1983, p. 320. 